\title{
Orchids in Rolpa district of Western Nepal: Documentation, stock, trade and conservation
}

\author{
P. N. Koirala ${ }^{1}$, D. Pyakurel ${ }^{2}$ and K. Gurung ${ }^{3}$
}

\begin{abstract}
Orchids are perennial, epiphytic, terrestrial or lithophytic herbs with roots having multilayered spongy tissues. In Nepal, 363 species of orchids are organized into 97 genera. Orchids fall under the Convention on International Trade in Endangered Species of Wild Fauna and Flora (CITES) Appendix II but do not fall under the legal protection of any existing national legislation. Habitat loss, forest destruction and degradation and over-exploitation have posed threats to the conservation of orchids in Nepal. The current study aims to document the orchids and estimate the stock of Dendrobium denudans and Dendrobium eriiflorum in a few potential locations of Rolpa district. A total of 36 species were documented in the surveyed 17 Village Development Committees (VDCs). Among them, 31 species were identified up to species level, two species up to generic level and the remaining three were unidentifed. The total stock of $D$. denudans was highest in Uwa VDC with $11018.08 \mathrm{~kg}$ followed by Seram VDC with the stock of $9982.57 \mathrm{~kg}$. Similarly, D. eriiflorum stock in Seram, Siuri and Jaimakasala VDCs were $22750.01 \mathrm{~kg}, 7039.67 \mathrm{~kg}$ and $4933.46 \mathrm{~kg}$, respectively. This study recommends a systematic research on the propagation technique; complete indexing of orchids; and inclusion of orchids in the Red Data Book on the threatened and endangered species. Orchid reserves in orchid hotspots should be established for the preservation and promotion of regeneration activities. The rare and endangered species should be preserved in botanic gardens. In addition to scientific attempts, the country should launch and implement a very firm regulation for their protection.
\end{abstract}

Key words: Orchids, Dendrobium denudans, Dendrobium eriiflorum, distribution, conservation, Rolpa district

$\mathbf{O}$ rchids are notably diversified in the moist tropics of both hemispheres and the majority is epiphytes in forests. Most of the temperate and almost all of the alpine genera are terrestrial, while some are lithophytes. The orchids (Nepali name: Sunakhari, Sungava, Jivanti; Family: Orchidaceae) are one of the largest family of flowering plants comprising more than 17,000 species in the world. In Nepal 363 species of orchids are organized into 97 genera (Rajbhandari and Bhattarai, 2001).

Orchids are perennial or rarely annual, epiphytic, terrestrial or lithophytic herbs with roots having multi-layered spongy tissue. They are capable of absorbing and storing considerable quantity of moisture from the atmosphere. In terrestrial species, the roots are often swollen into tubers or stems from corms or rhizomes. Stems of epiphytic species are often thickened to form a pseudo-bulb with adventitious roots.
The first systematic orchid collection in Nepal was done by Hamilton in 1802 and Wallich in 1820 from Kathmandu valley (Rajbhandari, 1976) and their collections were studied by David Don in 1825-26. Hara et al. (1978), Banerji (1978) and Banerji and Pradhan (1984) have also listed and described orchids of Nepal. Since then, several orchids new to Nepal have been reported by Cribb and Tang (1983); Bailes (1985); Wood (1986 and 1989); DuPuy and Cribb (1988); Bajracharya et al. (1993); Bania et al. (1993); Rajbhandari and Bhattarai (1995-96); Pearce and Cribb (1996); Rajbhandari et al. (1997, 1998); Shakya and Bania (1998); Shakya and Chaudhary (1999) and Shakya (2000).

Habitat loss, forest destruction and degradation and over exploitation have threatened the conservation of orchids in Nepal. Detailed studies to understand the conservation status of orchids of Nepal are still

\footnotetext{
Leasehold Forestry and Livestock Programme, Department of Forests, Babarmahal, Kathmandu. Email: koiralapn@yahoo.com

2 Freelance Botany Consultant, Kathmandu.

3 Freelance Botany Consultant, Kathmandu.
} 
unavailable. However, the Government of Nepal published notification on the gazette dated 2 Baishakh, 2065 (14 April, 2008) stating the permit to collect wild orchids, which was banned before, was now open for trade. Due to this notification, some rare and endangered orchid species have come under the threat of over-exploitation.

\section{Study context}

Up to the fiscal year 2063/064 B.S. (2006 A.D), 2353 $\mathrm{kg}$ of orchids had been traded from Rolpa district, generating a revenue of Rs 7459 (DFO Rolpa, 2008). But the enumeration of orchid species, their status, hotspot mapping and the species that are traded have not been assessed to date.

Thus, this study intends to document orchids, identify the orchid hotspots and quantify the traded orchids for the selected Village Development Committees (VDCs) of Rolpa district. Subsequently, the study has identified threat status of the species in the district and recommended conservation strategies.

Most of the terrestrial and a few epiphytic orchids were not in flowering stage so some of them could not be identified. Current stock has been calculated for only the traded species (Dendrobium denudans and D. eriiflorum).

\section{Study area}

Rolpa district lies in Rapti zone of the Mid Western Region, Nepal. Spread over 187150 ha, Rolpa is located between $28^{\circ} 8^{\prime}-28^{\circ} 38^{\prime} \mathrm{N}$ latitude and $83^{\circ} 10^{\prime}$ $84^{\circ} 9^{\prime} \mathrm{E}$ longitude, with altitudinal range of 701-3639 $\mathrm{m}$, representing tropical, sub-tropical, temperate and sub-alpine types of climate. The district is surrounded by Rukum to the North, Baglung and Pyuthan to the East, Salyan to the West and Pyuthan and Dang to the South. Of the total land area, 94097 ha $(50.28 \%)$ is covered with forest and grazing land covers 32699 ha $(17.47 \%)$ area of the district. The maximum temperature recorded was $31.2^{\circ} \mathrm{C}$ and the minimum temperature was $3.6^{\circ} \mathrm{C}$. Similarly, the maximum annual rainfall was recorded as $1836 \mathrm{~mm}$ and the minimum annual rainfall was $1388 \mathrm{~mm}$. The ecological zones of the district encompass Sal, Chir Pine, Alder, Himalayan Oak-Laurel, Mixed Rhododendron-Oak, Temperate Mountain Oak,
Rhododendron, sub-alpine scrub and sub-alpine meadow forests and vegetation types. This study focused on 17 VDCs of Rolpa district (Fig 1).

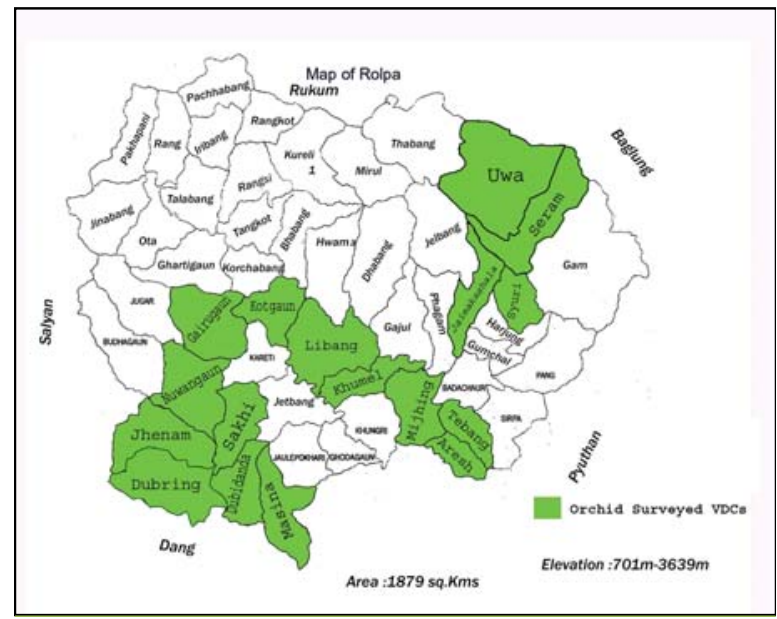

Fig 1: Map of Rolpa showing VDCs surveyed for orchids

\section{Study methods}

Primary data were collected using different tools like observation, measurement, interviews, consultation with key informants and other relevant Participatory Rapid Appraisal (PRA) tools. Forest guards, herbs traders, hotel owners and farmers were the key informants interviewed. Verbal open ended questions were used in interviews and discussions. Secondary information was collected from related publications, research papers, data from District Forest Office (DFO) and other documents. The secondary data were collected for the verification of primary data and additional information.

Orchid sampling and observation were conducted in defined habitats. Identification of orchid hotspots was done systematically by observing the abundance, habitat, forest types, moisture, altitude and aspects. Global Positioning System (GPS) coordinates/data were recorded to locate the hotspots of orchids in their specific habitats. Habitats of epiphytic orchids were identified on the basis of researchers' knowledge. Observed orchids were identified visually. Unidentified species were collected and identified by consulting the reference literatures such as Polunin and Stainton (1984), Stainton (1988), Rajbhandari and Bhattarai (2001), Milleville and Shrestha (2004). Documentations of all available orchids were carried out according to Rajbhandari and Bhattarai (2001) and Press et al. (2000). 
Abundance of terrestrial and epiphytic species is defined as the number of species "A" found in all plots to the total area of the plots per hectare. It was calculated by using the following formula of Zobel et al. (1987):

The following steps were carried out to find out the abundance of epiphytic orchids.

\section{Steps followed to quantify the epiphytic orchids}

- Number of host plants was counted in a quadrat of $10 \mathrm{~m}$ x $10 \mathrm{~m}$.

- Number of orchid patches per tree (in a quadrat of $10 \mathrm{~m} \times 10 \mathrm{~m}$ ) was counted.

- Total patches were calculated to find the mean value (patch per tree).

- Number of plants per patch was counted and its mean value was calculated.

- Finally the number of patches (and plant per patch of orchid) was calculated by multiplying the mean value of patch per tree to the density of host plant.

- Quantification was done by multiplying

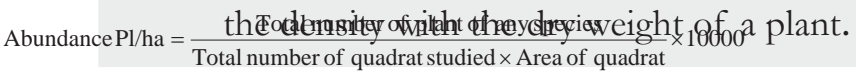

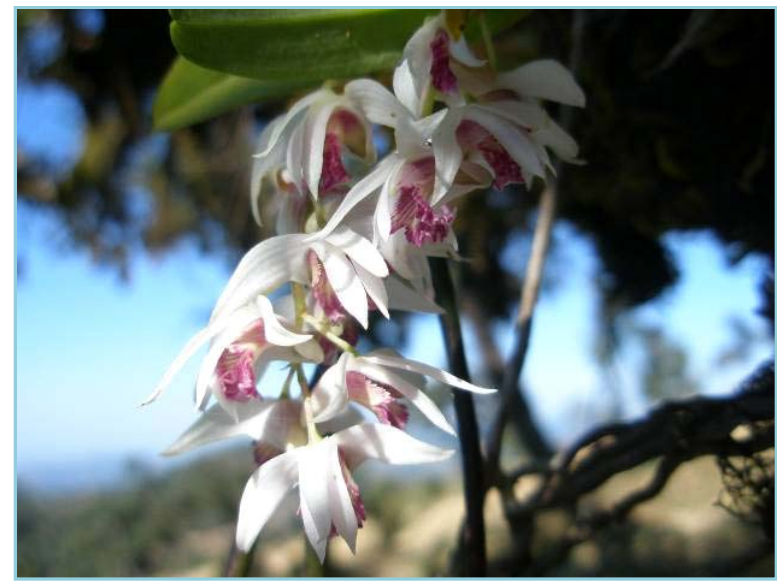

Fig 2: Dendrobium denudans
Traded orchids were collected from the study sites in patches. Number of individuals in each patch was counted. Fresh weight of bulb/pseudo-bulb was recorded in the field with the help of a balance. They were sun dried for 15-20 days according to the nature of species and dry weight of each bulb/pseudo-bulb was measured with a digital balance. Finally, the total stock of traded orchid species per hectare was calculated.

Total stock of traded orchids in each VDC was calculated by multiplying the availability (per hectare) to the area of corresponding forest type (expressed in ha) as per the data provided by DFO, Rolpa.

\section{Documentation of orchids in Rolpa}

Altogether 36 species of orchids were recorded and identified in the studied 17 VDCs of Rolpa district. Among them, 31 species were identified up to species level, two species were identified up to generic level and the remaining three were not identifiable. The list of recorded orchids is given in Table 1. A total of seven species of Dendrobium were recorded from the surveyed VDCs. Similarly, four species of Coelogyne were recorded. Of all the recorded orchid species, two species of Dendrobium (D. denudans and D. eriiflorum) are traded from the district.

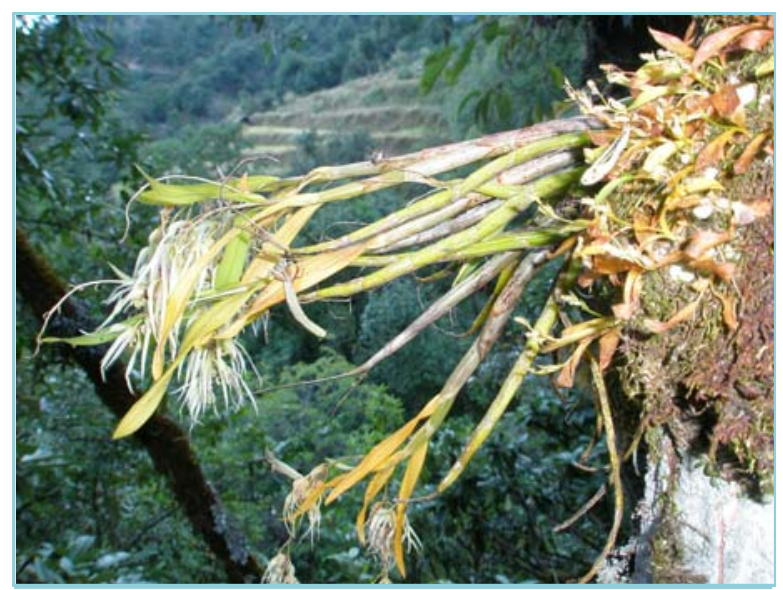

Fig 3: Dendrobium eriiflorum 
Table 1: Orchid species in the surveyed VDCs of Rolpa district

\begin{tabular}{|c|c|c|c|c|c|}
\hline SN & Scientific Name & Habitat & Distribution (m) & Flowering & Remarks \\
\hline 1 & Aerides multiflora & $\mathrm{E}$ & $800-1100$ & May-Jul & \\
\hline 2 & Aerides odorata & $\mathrm{E}$ & $800-1200$ & May-Jul & \\
\hline 3 & Bulbophyllum careyanum & $\mathrm{E}$ & $800-2100$ & Oct-Dec & \\
\hline 4 & Bulbophyllum viridiflorum & $\mathrm{E}$ & $1100-2300$ & Jul-Oct & \\
\hline 5 & Calanthe tricarinata & $\mathrm{T}$ & $1500-3200$ & Jun-Jul & \\
\hline 6 & Chiloschista usneoides & $\mathrm{E}$ & $1600-1700$ & Feb-Apr & \\
\hline 7 & Cleisostema sp. & $\mathrm{E}$ & 1700 & & Masina VDC \\
\hline 8 & Coelogyne corymbosa & $\mathrm{E}, \mathrm{T}$ & $1500-2900$ & Mar-May & \\
\hline 9 & Coelogyne cristata & $\mathrm{E}, \mathrm{T}$ & $1400-2500$ & Feb-Apr & \\
\hline 10 & Coelogyne flaccida & $\mathrm{E}$ & $900-1400$ & Apr-June & \\
\hline 11 & Coelogyne ovalis & $\mathrm{E}$ & $1300-2100$ & Sept-Dec & \\
\hline 12 & Cymbidium elegans & $\mathrm{E}$ & $2100-2500$ & Sept-Nov & \\
\hline 13 & Cymbidium iridioides & $\mathrm{E}$ & $1300-2400$ & Sept-Dec & \\
\hline 14 & Cypripedium himalaicum & $\mathrm{T}$ & $3000-3600$ & Jun-Aug & \\
\hline 15 & Dactylorbiza hatagirea & $\mathrm{T}$ & $3000-4000$ & Jun-Jul & \\
\hline 16 & Dendrobium aphyllum & $\mathrm{E}$ & $800-1500$ & Apr-Jun & \\
\hline 17 & Dendrobium bicameratum & $\mathrm{E}$ & $1400-2400$ & Jul-Aug & \\
\hline 18 & Dendrobium chryseum & $\mathrm{E}$ & $1200-2100$ & Apr-Jun & \\
\hline 19 & Dendrobium denudans & $\mathrm{E}, \mathrm{L}$ & $1000-2200$ & Apr-Sept & Traded species \\
\hline 20 & Dendrobium eriiflorum & $\mathrm{E}$ & $1500-2100$ & Sept-Oct & Traded species \\
\hline 21 & Dendrobium heterocarpum & $\mathrm{E}$ & $1000-1400$ & Apr-May & \\
\hline 22 & Dendrobium longicornu & $\mathrm{E}$ & $1300-2900$ & Sept-Nov & \\
\hline 23 & Epigeneium amplum & E, L & $1300-2100$ & Sept-Nov & \\
\hline 24 & Gastrochilus calceolaris & $\mathrm{E}$ & $900-2300$ & Feb-Mar & \\
\hline 25 & Herminium lanceum & $\mathrm{T}$ & $1100-3500$ & Jul-Sep & \\
\hline 26 & Kingidium taenialis & E, L & $1500-2300$ & Apr-Jun & \\
\hline 27 & Oberonia acaulis & $\mathrm{E}$ & $600-2100$ & Sept-Dec & \\
\hline 28 & Oberonia sp. & $\mathrm{E}$ & $1100-1700$ & & Siuri VDC \\
\hline 29 & Pleione hookeriana & $\mathrm{T}$ & $2200-3700$ & May-Jun & \\
\hline 30 & Rhynchostylis retusa & $\mathrm{E}$ & 800-1800 & May-Jul & \\
\hline 31 & Satyrium nepalense & $\mathrm{T}$ & $1500-3600$ & July-Sept & \\
\hline 32 & Spiranthes sinensis & $\mathrm{T}$ & $800-3600$ & Apr-Aug & \\
\hline 33 & Vanda cristata & $\mathrm{E}$ & $1200-2300$ & Mar-May & \\
\hline 34 & Unidentified & $\mathrm{E}$ & $1900-2200$ & & Liwang VDC \\
\hline 35 & Unidentified & $\mathrm{E}$ & $1900-2200$ & & Liwang VDC \\
\hline 36 & Unidentified & $\mathrm{E}$ & $1900-2200$ & & Liwang VDC \\
\hline
\end{tabular}

$\mathrm{E}=$ Epiphytic; $\mathrm{T}=$ Terrestrial; $\mathrm{L}=$ Lithophytic 


\section{Distribution of orchids in the studied VDCs of Rolpa}

The VDC wise list of recorded orchids are given in Table 2 .

Table 2: List of recorded orchids in the studied VDCs of Rolpa district

\begin{tabular}{|c|c|c|c|}
\hline SN & VDCs & Recorded orchid species & Abundant orchids \\
\hline 1 & Jhenam & $\begin{array}{l}\text { A. multiflora, A. odorata, C. corymbosa, C. cristata, C. ovalis, } \\
\text { D. aphyllum, D. bicameratum, D. denudans, D. longicornu, } \\
\text { G. calceolaris, H. lanceum, K. taenialis, R. retusa, V. cristata, } \\
\text { S. nepalense }\end{array}$ & $\begin{array}{l}\text { C. ovalis, D. denudans, } \\
\text { K. taenialis }\end{array}$ \\
\hline 2 & Dubring & $\begin{array}{l}\text { A. multiflora, A. odorata, C. corymbosa, C. cristata, C. ovalis, } \\
\text { D. aphyllum, D. bicameratum, D. denudans, D. longicornu, } \\
\text { G. calceolaris, H. lanceum, K. taenialis, R. retusa, V. cristata, } \\
\text { S. nepalense, Cleisostema sp. }\end{array}$ & $\begin{array}{l}\text { C. ovalis, D. aphyllum, } \\
\text { K. taenialis }\end{array}$ \\
\hline 3 & Sakhi & $\begin{array}{l}\text { A. multiflora, A. odorata, C. corymbosa, C. cristata, C. ovalis, } \\
\text { D. aphyllum, D. bicameratum, D. denudans, D. longicornu, } \\
\text { G. calceolaris, H. lanceum, K. taenialis, R. retusa, V. cristata, } \\
\text { S. nepalense }\end{array}$ & $\begin{array}{l}\text { C. ovalis, C. corymbosa, } \\
\text { C. cristata }\end{array}$ \\
\hline 4 & Dubidanda & $\begin{array}{l}\text { A. multiflora, A. odorata, C. corymbosa, C. cristata, C. ovalis, } \\
\text { D. aphyllum, D. bicameratum, D. denudans, D. longicornu, } \\
\text { G. calceolaris, H. lanceum, K. taenialis, R. retusa, V. cristata, } \\
\text { S. nepalense, Cleisostema sp., S. sinensis }\end{array}$ & $\begin{array}{l}\text { D. apbyllum, D. denudans, } \\
\text { C. corymbosa }\end{array}$ \\
\hline 5 & Masina & $\begin{array}{l}\text { A. multiflora, A. odorata, C. corymbosa, C. cristata, C. ovalis, } \\
\text { D. aphyllum, D. bicameratum, D. denudans, D. longicornu, } \\
\text { G. calceolaris, H. lanceum, K. taenialis, R. retusa, V. cristata, } \\
\text { S. nepalense, Cleisostema sp. }\end{array}$ & $\begin{array}{l}\text { C. ovalis, D. longicornu, } \\
\text { V. cristata }\end{array}$ \\
\hline 6 & Nuwagaun & $\begin{array}{l}\text { A. multiflora, A. odorata, C. corymbosa, C. cristata, C. ovalis, } \\
\text { D. aphyllum, D. bicameratum, D. denudans, D. longicornu, } \\
\text { G. calceolaris, H. lanceum, K. taenialis, R. retusa, V. cristata, } \\
\text { S. nepalense }\end{array}$ & $\begin{array}{l}\text { C. ovalis, C. corymbosa, } \\
\text { C. cristata }\end{array}$ \\
\hline 7 & Gairigaun & $\begin{array}{l}\text { A. multiflora, A. odorata, C. corymbosa, C. cristata, C. ovalis, } \\
\text { D. aphyllum, D. bicameratum, D. denudans, D. longicornu, } \\
\text { G. calceolaris, H. lanceum, K. taenialis, R. retusa, V. cristata, } \\
\text { S. nepalense, S. sinensis }\end{array}$ & $\begin{array}{l}\text { C. corymbosa, C. cristata, } \\
\text { D. apbyllum }\end{array}$ \\
\hline 8 & Kotgaun & $\begin{array}{l}\text { A. multiflora, A. odorata, C. corymbosa, C. cristata, C. ovalis, } \\
\text { D. aphyllum, D. bicameratum, D. denudans, D. longicornu, } \\
\text { G. calceolaris, H. lanceum, K. taenialis, R. retusa, V. cristata, } \\
\text { S. nepalense }\end{array}$ & $\begin{array}{l}\text { C. corymbosa, D. denudans, } \\
V . \text { cristata }\end{array}$ \\
\hline 9 & Liwang & $\begin{array}{l}\text { A. multiflora, A. odorata, B. viridiflorum, C. usneoides, } \\
\text { C. corymbosa, C. cristata, C. flaccida, C. ovalis, D. aphyllum, } \\
\text { D. bicameratum, D. chryseum, D. denudans, D. beterocarpum, } \\
\text { D. longicornu, E. amplum, G. calceolaris, H. lanceum, K. taenialis, } \\
\text { O. acaulis, R. retusa, V. cristata, Unidentified } 3 \text { species }\end{array}$ & $\begin{array}{l}\text { C. corymbosa, D. denudans, } \\
\text { D. longicornu }\end{array}$ \\
\hline
\end{tabular}




\begin{tabular}{|c|c|c|c|}
\hline SN & VDCs & Recorded orchid species & Abundant orchids \\
\hline 10 & Khumel & $\begin{array}{l}\text { A. multiflora, A. odorata, B. viridiflorum, C. usneoides, } \\
\text { C. corymbosa, C. cristata, C. flaccida, C. ovalis, D. aphyllum, } \\
\text { D. bicameratum, D. chryseum, D. denudans, D. beterocarpum, } \\
\text { D. longicornu, E. amplum, G. calceolaris, H. lanceum, } \\
\text { K. taenialis, R. retusa, V. cristata }\end{array}$ & $\begin{array}{l}\text { C. corymbosa, D. longicornu, } \\
\text { D. bicameratum }\end{array}$ \\
\hline 11 & Mijhing & $\begin{array}{l}\text { A. multiflora, A. odorata, C. corymbosa, C. cristata, } \\
\text { D. aphyllum, D. bicameratum, D. chryseum, D. eriiflorum, } \\
\text { D. beterocarpum, D. longicornu, G. calceolaris, H. lanceum, } \\
\text { K. taenialis, O. acaulis, R. retusa, V. cristata }\end{array}$ & $\begin{array}{l}D . \text { bicameratum, R. retusa, } \\
V . \text { cristata }\end{array}$ \\
\hline 12 & Jaimakasala & $\begin{array}{l}\text { A. multiflora, A. odorata, C. usneoides, C. corymbosa, } \\
\text { C. cristata, C. flaccida, C. ovalis, D. aphyllum, } \\
\text { D. bicameratum, D. chryseum, D. denudans, D. eriiflorum, } \\
\text { D. heterocarpum, D. longicornu, E. amplum, H. lanceum, } \\
\text { O. acaulis, P. hookeriana, R. retusa, V. cristata, S. sinensis, } \\
\text { Oberonia sp. }\end{array}$ & $\begin{array}{l}\text { D. denudans, D. eriiflorum, } \\
\text { E. amplum, O. acaulis }\end{array}$ \\
\hline 13 & Seram & $\begin{array}{l}\text { A. multiflora, A. odorata, C. usneoides, C. corymbosa, } \\
\text { C. cristata, C. flaccida, C. ovalis, D. aphyllum, D. bicameratum, } \\
\text { D. chryseum, D. denudans, D. eriiflorum, D. heterocarpum, } \\
\text { D. longicornu, H. lanceum, O. acaulis, P. hookeriana, R. retusa, } \\
\text { V. cristata, Oberonia sp. }\end{array}$ & $\begin{array}{l}\text { D. bicameratum, D. denudans, } \\
\text { D. eriiflorum, O. acaulis }\end{array}$ \\
\hline 14 & Uwa & $\begin{array}{l}\text { A. odorata, C. tricarinata, C. corymbosa, C. cristata, C. flaccida, } \\
\text { C. ovalis, C. himalaicum, D. hatagirea, D. aphyllum, } \\
\text { D. bicameratum, D. denudans, D. heterocarpum, D. longicornu, } \\
\text { E. amplum, H. lanceum, K. taenialis, O. acaulis, P. hookeriana, } \\
\text { R. retusa, S. nepalense, V. cristata }\end{array}$ & $\begin{array}{l}\text { C. corymbosa, D. denudans, } \\
\text { E. amplum, O. acaulis }\end{array}$ \\
\hline 15 & Siuri & $\begin{array}{l}\text { A. multiflora, A. odorata, C. usneoides, C. corymbosa, } \\
\text { C. cristata, C. flaccida, C. ovalis, D. aphyllum, D. bicameratum, } \\
\text { D. chryseum, D. denudans, D. eriiflorum, D. heterocarpum, } \\
\text { D. longicornu, H. lanceum, O. acaulis, P. hookeriana, R. retusa, } \\
\text { V. cristata, S. sinensis, Oberonia sp. }\end{array}$ & $\begin{array}{l}\text { D. bicameratum,D. denudans, } \\
\text { D. eriiflorum, O. acaulis }\end{array}$ \\
\hline 16 & Aresh & $\begin{array}{l}\text { A. multiflora, A. odorata, C. corymbosa, C. cristata, D. aphyllum, } \\
\text { D. longicornu, H. lanceum, K. taenialis, O. acaulis, R. retusa, } \\
\text { V. cristata }\end{array}$ & $\begin{array}{l}\text { A. multiflora, C. cristata, } \\
\text { V. cristata }\end{array}$ \\
\hline 17 & Tewang & $\begin{array}{l}\text { A. multiflora, A. odorata, C. corymbosa, C. cristata, } \\
\text { D. aphyllum, D. longicornu, H. lanceum, K. taenialis, O. acaulis, } \\
\text { R. retusa, V. cristata }\end{array}$ & $\begin{array}{l}\text { A. multiflora, C. cristata, } \\
\text { V. cristata }\end{array}$ \\
\hline
\end{tabular}




\section{Habitat of orchids}

The mid altitudes between 1000-2300 m of the studied VDCs harbour the highest number of epiphytic orchid species in Rolpa district. Few terrestrial orchid species grow on meadows and underlying forest covers ranging from sub-tropical to sub-alpine regions in the studied VDCs. The suitability of luxuriant growth of epiphytic orchids in the mid-hills is due to the moisture rich, mossy habitat as a result of high cloud formation.

Typically, two times a day the mid altitudes benefit from a 'cloud bath' resulting from the rising and falling of cloud line. As a result of such a daily weather cycle in the mid-hills, the medium bark of trees/shrubs decompose quickly into anaerobic sludge combined with lots of air movement and the strong light seems to make orchids sturdy and resilient.

\section{Host plants of orchids}

Most of the orchid species were found growing on Angeri (Lyonia ovalifolia), Banjh (Quercus leucotrichophora), Katus (Castanopsis indica), Lali Gurans (Rhododendron arboreum) and Kaphal (Myrica esculenta) in sub-tropical and temperate regions. Similarly, Chiuri (Diploknema butyracea), Mauwa (Engelhardtia spicata) and Sal (Shorea robusta).

Among all the host plants, Angeri and Lali Gurans host more than 21 orchid species each. Similarly, Katus hosts 19 species, Banjh hosts 18 species, Kaulo hosts 13 species, Mauwa, Kaphal and Chiuri host 12 species each.

Gymnosperms are not good hosts for orchids but Khote salla (Pinus roxburgbii) hosts three species of Dendrobium and Rhynchostylis retusa. Three species of orchids are lithophytic whereas nine species are terrestrial (Table 1).

\section{Hotspots of orchids}

Orchid habitat comprises of undisturbed mixed broadleaved forest with good moisture content. This type of habitat harbours many kinds of orchids so, it is known as "Orchid Hotspot". Orchid hotspots have been identified in the forests of Jhenam, Dubring, Dubidanda, Masina, Sakhi, Nuwagaun, Gairigaun, Kotgaun, Liwang, Khumel, Jaimakasala, Uwa, Seram and Siuri VDCs. Orchid hotspots of surveyed VDCs are shown in Fig 4.
Traded orchids and their current stock

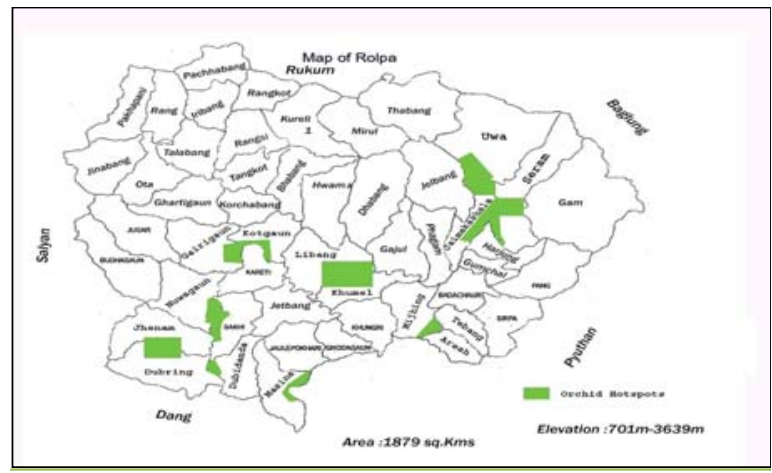

Fig 4: Map showing orchid hotspots in Rolpa district

According to the collectors and traders of orchids in Rolpa district, two species of orchids are traded because they fetch higher price (NRs. 150-200/kg). They were $D$. denudans and D. eriiflorum.

The abundance of D. denudans was highest in Liwang VDC (15360/ha) with a current stock of $23.42 \mathrm{~kg} /$ ha followed by Seram VDC with an abundance of $13800 /$ ha having a current stock of $21.04 \mathrm{~kg} / \mathrm{ha}$ and Uwa VDC with an abundance of $13150 /$ ha and a current stock of $20.05 \mathrm{~kg} / \mathrm{ha}$ (Table 3).

Similarly, the abundance of D. eriiflorum was highest in Siuri VDC (35530/ha) with the current stock of $54.18 \mathrm{~kg} / \mathrm{ha}$ followed by Seram VDC with the abundance of $31450 /$ ha having a current stock of $47.96 \mathrm{~kg} / \mathrm{ha}$ and Jaimakasala VDC with abundance of $26640 / \mathrm{ha}$ and current stock of $40.62 \mathrm{~kg} / \mathrm{ha}$.

\section{Assessment of the threat}

The wild orchids having high horticultural values especially in the cross national sectors, are posing a continued threat to wild populations in the forests. As a result, the wild habitat is perceived to be depleting because of habitat destruction. Since 2008, Nepal Government has lifted the ban on trade of wild orchids which were restricted before and has now permitted the export with CITES certification. Therefore, the over-exploitation of wild orchids by local vendors for sale to the traders/exporters has exerted a serious threat to mostly sub-tropical and few temperate epiphytic species. For this reason, the favourable orchid habitats are heavily disturbed and not given attention for conservation. Degradation and depletion of the habitats are critical threats for orchids. 
Table 3: Abundance and current stock of traded orchids

\begin{tabular}{|c|c|c|c|c|c|c|c|c|}
\hline $\mathrm{SN}$ & $\begin{array}{l}\text { Name of } \\
\text { VDC }\end{array}$ & $\begin{array}{l}\text { Traded } \\
\text { species }\end{array}$ & $\begin{array}{l}\text { No of } \\
\text { plants } \\
\text { patch }\end{array}$ & $\begin{array}{l}\text { No of } \\
\text { plants } \\
\text { /ha }\end{array}$ & $\begin{array}{l}\text { Stock } \\
\mathrm{kg} / \mathrm{ha}\end{array}$ & $\begin{array}{l}\text { Area of } \\
\text { broad } \\
\text { leaved } \\
\text { forest } \\
\text { (ha) }\end{array}$ & $\begin{array}{l}\text { Estimated } \\
\text { area of } \\
\text { orchid } \\
\text { distribution } \\
\text { (ha) }\end{array}$ & $\begin{array}{l}\text { Total } \\
\text { stock of } \\
\text { the area } \\
(\mathrm{kg}) *\end{array}$ \\
\hline 1 & Liwang & D. denudans & 8 & 15360 & 23.42 & 646.49 & 258.60 & 6057.35 \\
\hline 2 & Masina & D. denudans & 4 & 2320 & 3.54 & 325.92 & 130.37 & 461.24 \\
\hline 3 & Dubring & D. denudans & 3 & 1170 & 1.78 & 524.55 & 209.82 & 374.32 \\
\hline 4 & Dubidanda & D. denudans & 3 & 1560 & 2.38 & 249.95 & 99.98 & 237.85 \\
\hline 5 & Sakhi & D. denudans & 3 & 2430 & 3.70 & 298.83 & 119.53 & 442.27 \\
\hline 6 & Jhenam & D. denudans & 3 & 2610 & 3.98 & 353.36 & 141.34 & 562.55 \\
\hline 7 & Nuwagaun & D. denudans & 3 & 2820 & 4.30 & 1089.85 & 435.94 & 1874.54 \\
\hline 8 & Gairigaun & D. denudans & 5 & 11450 & 17.46 & 826.92 & 330.77 & 5775.54 \\
\hline 9 & Kotgaun & D. denudans & 4 & 3960 & 6.04 & 195.37 & 78.15 & 471.94 \\
\hline 10 & Khumel & D. denudans & 4 & 5880 & 8.97 & 250.30 & 100.12 & 897.78 \\
\hline 11 & Mijhing & D. eriiflorum & 9 & 9810 & 14.96 & 232.49 & 93.00 & 1391.22 \\
\hline \multirow[t]{2}{*}{12} & Jaimakasala & D. eriiflorum & 18 & 26640 & 40.63 & 303.59 & 121.44 & 4933.46 \\
\hline & & D. denudans & 6 & 9240 & 14.09 & 303.59 & 121.44 & 1711.15 \\
\hline \multirow[t]{2}{*}{13} & Seram & D. erïflorum & 17 & 31450 & 47.96 & 1185.86 & 474.34 & 22750.01 \\
\hline & & D. denudans & 6 & 13800 & 21.05 & 1185.86 & 474.34 & 9982.57 \\
\hline 14 & Uwa & D. denudans & 5 & 13150 & 20.05 & 1373.62 & 549.45 & 11018.08 \\
\hline \multirow[t]{3}{*}{15} & Siuri & D. eriiflorum & 19 & 35530 & 54.18 & 324.81 & 129.92 & 7039.67 \\
\hline & & D. denudans & 4 & 8000 & 12.20 & 324.81 & 129.92 & 1585.07 \\
\hline & Total & & & & & 9996.17 & 3998.47 & 77566.61 \\
\hline
\end{tabular}

* Of the broadleaved forest area of the surveyed VDCs, it is assumed that only $40 \%$ of the forest area hosts orchids. Based on this assumption, total stocks of orchids were calculated. However, total stock of orchids comprises all size and age classes and cannot be harvested in totality.

Similarly, weak legal enforcement and conservation gaps are other factors causing the threats to orchid species. The CITES inland law has not been formulated yet for the country and very few field technicians are aware of the value of orchids. Furthermore, very few forest technicians could identify orchids in the wild form. Wild forest patches are the key habitat of orchids but rarely have such species been included in regular monitoring system under the DFO administrative mechanism. Moreover, inventory (including abundance, harvestable stock and distribution) have not been mainstreamed in the community forestry operational plans and the district periodic plans. At the same time, high level policy makers also lack awareness on orchid status in the country. Issuing permits for collection and transit is not user-friendly or environmentally sound as assumed by the high level policy makers and implementing the top-down orders by the DFO has created confusions for maintaining regulation and establishing a sustainable harvesting system.

\section{Strategies for conservation and management}

Orchids fall under Appendix II category which is defined as species not yet threatened but which could become endangered if trade is not controlled. Collection and trade of orchids do not fall under the jurisdiction of CITES or any existing legislation. However, it is envisaged that with the development and enactment of regulations under the endangered species (protection, conservation and regulation of trade) act, illegal trade and uncontrolled harvesting of orchids will be addressed.

\section{Sustainable conservation and protection of the orchid hotspots}

\section{In-situ /ex-situ conservation}

Habitat/species management areas (equivalent to IUCN Category IV) should be established where the 
ecosystems are healthy and a number of species present are threatened by proposed habitat alteration such as development or mining. For this, recovery/ management plan (zoning for hotspots) for endangered orchid species should be developed and implemented. For ex-situ conservation, a few rescue centres should be established: at least two rescue centres, to house illegally exported orchids because the illegally transported en-route species have a very high value in the market. In addition, a gene bank could preserve the endangered orchid species. From another perspective, encouraging the artificial propagation from seeds and tissue culture for commercial objectives could encourage private growers to invest if granted tax exemptions for export and import of such materials. In Nepal, a large tracts of forests have been handed over to community users; therefore, the community level awareness and involvement for conservation and propagation is of utmost importance for the conservation of big habitat areas.

\section{Strengthening regulatory mechanism}

Conservation and management can be achieved through amendments of the Forest Act 1993 and Plant Protection Act 2029 to incorporate the protection of endangered and endemic orchid species and establish quota restrictions on commercial species. The Acts and by-laws should conform to the CITES protocol. A periodic review of the orchids on the protected lists should be carried out for nomenclature changes and addition or deletion of the species. A detailed field collection policy should be developed for field level implementation to prevent over-exploitation of the wild orchids and incorporated into the national legislation. It can be regulated by creating an endorsement mechanism for the commercial exporters and importers.

\section{Education and research}

Technological information seems lacking in the whole hierarchical levels of forestry organization. In order to address this lacuna, firstly, training programmes for the identification of orchid species for DFO staff, Customs Officers, Taxonomists, Protected Area Rangers, Plant Quarantine Officers and other relevant persons involved in the issuing of permits and security at airports should be organized regularly. Secondly, the training should focus on artificial propagation of commercially viable species. Thirdly, public education awareness campaign programmes should be organized through various extension methods and through mass media. Finally, the government and research institutes, including educational institutions, should promote research on conservation modalities and scientific cultivation.

\section{Conclusion and recommendation}

Orchids are among the most beautiful ornamental plants with medicinal and horticultural importance as well. Rolpa district is rich in orchid species resources, with 36 species of terrestrial, epiphytic and lithophytic orchids identified in the 17 VDCs studied in the district. Orchid habitat hotspots and host plants were identified within the community forests as well as government managed forests at altitudes of 1000-2300 $\mathrm{m}$ in humid and moisture rich, mixed broadleaved forest of the surveyed VDCs.

The assessment of the current stock of traded orchid species revealed that the abundance of $D$. denudans was the highest in Liwang VDC (15360/ha) with a current stock of $23.42 \mathrm{~kg} / \mathrm{ha}$ followed by Seram VDC with an abundance of $13800 /$ ha having a current stock of $21.04 \mathrm{~kg} / \mathrm{ha}$ and Uwa VDC with an abundance of $13150 /$ ha and a current stock of $20.05 \mathrm{~kg} / \mathrm{ha}$.

Regarding abundance, D. eriiflorum was found to be the highest in Siuri VDC (35530/ha) with a current stock of $54.18 \mathrm{~kg} /$ ha followed by Seram VDC with the abundance of $31450 /$ ha having current stock of $47.96 \mathrm{~kg} / \mathrm{ha}$ and Jaimakasala VDC with an abundance of $26640 / \mathrm{ha}$ and a current stock of $40.62 \mathrm{~kg} / \mathrm{ha}$.

Of the total broadleaved forest areas in the surveyed VDCs, it was assumed that only $40 \%$ of the forest areas hosts orchids. Based on this assumption, the total stock of orchids was calculated. The total stock of $D$. denudans was recorded highest in Uwa VDC with $11018.08 \mathrm{~kg}$ followed by Seram VDC with a stock of $9982.57 \mathrm{~kg}$ and Liwang VDC with a total stock of $6057.35 \mathrm{~kg}$. Similarly, the stock of $D$. eriiflorum was highest in Seram, Siuri and Jaimakasala with the total stocks of $22750.01 \mathrm{~kg}, 7039.67 \mathrm{~kg}$ and $4933.46 \mathrm{~kg}$, respectively. However, the total stock of orchids comprising of all size and age classes cannot be harvested in totality. 
Due to the habitat loss, forest destruction, degradation and over-exploitation of beautiful and medicinal orchids for trade, there are threats to the conservation of orchids in the district. Conservation has not been sensitive to the need of orchids. Therefore, detailed assessment to understand the current stock and overall conservation status of orchids in the district should be conducted, and this is still lacking. How much stocking is the optimal for sustainable conservation has not been calculated yet; therefore, this needs to be researched.

Legal arrangements with mass awareness programme should be mainstreamed in the regular annual activities in DFO and other conservation oriented programmes. A field collection policy should be developed to prevent the over-exploitation of wild orchids and incorporate them into the management plan of community forests as well as government managed forests. Similarly, artificial propagation and in-situ conservation may also have more importance in the conservation effort. For this, host plant species conservation and protection in natural form is necessary for arresting the depletion rate.

The Government should develop orchid hotspots areas for the eco-tourism promotion, so that the local stakeholders can earn some kind of income. For the local communities, it could be facilitated through beautiful orchids. A gene bank of endangered species should be established and maintained. Awareness activities and training programmes on identification of the orchid species should also be organized.

\section{Acknowledgements}

The authors acknowledge Livelihoods and Forestry Programme (LFP) for funding this study. Mr. P. Budhathoki, District Programme Coordinator, LFP, DFO field staff and local community people of Rolpa deserve our thanks for advising and assisting in the documentation of orchid species.

\section{References}

Bailes, C. P. 1985. Orchids in Nepal. The Conservationand Development of a Natural Resource. Advisory Report and Recommendations. Royal Botanic Gardens, Kew, London, UK.

Bajracharya, D., Shakya, L. R. and Chettri, M.K. 1993. Uncifera lancifolia (King \& Pantl.) Schtr.: A new record of orchid from Nepal Himalaya. In $X V$ International Botanical Congress: Abstracts, August 28September 3, 1993, Yokohama, Japan.

Banerji, M.L. and Pradhan, P. 1984. Orchids of Nepal. J. Cramer, Vaduz, Liechtenstein.

Banerji, M.L. 1978. Orchids of Nepal. Bishen Singh Mahendra Pal Singh, Dehra Dun, India.

Bania, A.M.S., Shakya, L.R., Chettri, M.K. and Bajracharya, D. 1993. Coelogyne fuscescens var. veridiflorum $\mathrm{U} C$ Pradhan, A new record of orchid from Nepal Himalaya. In XV International Botanical Congress: Abstracts, August 28-September 3, 1993, Yokohama, Japan.

Cribb, P.J. and Tang, C.Z. 1983. The Genus Pleione. Curtis's Bot. Mag. 184: 93-147.

DFO Rolpa. 2008. Annual Monitoring and Progress Report, District Forest Office, Rolpa, Nepal.

Don, D. 1825. Prodromus Florae Nepalensis. London, U.K.

DuPuy, D. and Cribb, P. 1988. The Genus Cymbidium. Christopher Helm/Timber Press, London, U.K.

Hara, H., Stearn W.T. and Williams, L.H. J. 1978. An Enumeration of the Flowering Plants of Nepal, Vol. 1. British Museum, Natural History, London, UK.

Milleville, R.de and Shrestha, T.B. 2004. Nepal Orchids in Pictures. Malla Prakashan, Kathmandu, Nepal.

Pearce, N. and Cribb, P. 1996.The Indo-Himalayan species of the genus Oreorchis. J. Orchid Soc. India 10 (1-2): 1-12.

Polunin, O. and Stainton, A. 1984. Flowers of the Himalaya. Oxford University Press, New Delhi, India.

Press, J.R., Shrestha, K.K. and Sutton, D.A. 2000. Annotated Checklist of the Flowering Plants of Nepal. The Natural History Museum, London, UK.

Rajbhandari, K.R. and Bhattarai, S. 1995-96. Cymbidium gammieanum King \& Pantl., A new record for Nepal. Nat. Hist. Soc. Nepal Bull. 5-6 (1-4): 2-3.

Rajbhandari K. R. and Bhattarai S. 1998. A new record of orchid for Nepal. Plant Research 1 (1): 12-13. 
Rajbhandari, K.R. and Bhattarai, S. 2001. Beautiful Orchids of Nepal. Kathmandu, Nepal.

Rajbhandari, K.R., Bhattarai, S. and Joshi, R. 1997. Calanthe anjanii S. Z. Lucksom, A New Record for Nepal. Nat. Hist. Soc. Nepal Bull. 7 (1-4): 18.

Rajbhandari, K.R. 1976. History of botanical explorations of Nepal. J. Bombay Nat. Hist. Soc. 73 (3): 468-481.

Shakya, L.R. and Bania, A.M.S. 1998. Pachystoma senile (Lindley) Reichb. f., A new record for Nepal. Newsletter of Himalayan Botany 24: 10-12.

Shakya, L.R. and Chaudhary, R.P. 1999. Taxonomy of Oberonia rufilabris and allied new species from the Himalaya. Harvard Papers in Botany 4 (1): $357-$ 363.
Shakya, L.R. 2000. Oberonia jenkensiana Griff. ex Lndl., A new record for Nepal. Rheedea 10 (2): 149-151.

Stainton A. 1988. Flowers of the Himalaya: A Supplement. Oxford University Press, New Delhi, India.

Wood J. J. 1986. Notes on Asiatic and New Guinea Orchidaceae. Kew Bull. 41 (4): 811-822.

Wood J. J. 1989. Eria extinctoria (Lindl.) oliver in Nepal. Die Orchidee 40 (6): 201-205.

Zobel, D.B., Jha P.K., Behan M.J. and Yadav, U.K.R. 1987. A Practical Manual for Ecology. Ratna Book Distributors, Kathmandu, Nepal. 